\title{
The effect of biopreparations on soybean germination ability and contamination with seed infection
}

\author{
Dina Kurilova* \\ V.S. Pustovoit All-Russian Research Institute of Oil Crops, Filatova street, 17, 350038 Krasnodar, \\ Russian Federation
}

\begin{abstract}
We studied the application efficiency of biopreparations for soybean seed treatment against seed infection. We established the positive effect of biopreparations application on the germination of soybean seeds. In the laboratory conditions, we observed the best protective effect against a complex of pathogens of seed infection in variants with the treatment of seeds with the laboratory samples of biopreparations 14-3 Pseudomonas chlororaphis, LC and Xk-1 Chaetomium olivacium, WP, as well as with biopreparations Trichoderma Veride 471, WP and Fitosporin-M, WP. In the field conditions, we observed an increase in plant density in relation to control by more than $10.0 \%$ in 14-3 P. chlororaphis, LC and Fitolavin, SC, Fitosporin-M and Trichoderma Veride 471, WP. Also, these biopreparations (except Fitolavin, SC) showed a good growth-stimulating effect.
\end{abstract}

\section{Introduction}

The most part of the total number of soybean diseases are seed-borne. In Russia, the most harmful among the complex of pathogens affecting soybean seeds are cotyledonous bacteriosis and fusarium of seeds and seedlings, which reduce field germination that causes a strong thinness of sowings [1]. The diseases pathogens enter the soil with seeds, accumulate in it and subsequently serve as a source of infection even when healthy seeds are sown [2].

In 2018-2019, we carried out a phytoexamination of soybean seeds (21 samples) and according to it the laboratory germination ranged from 64.5 to $97.5 \%$. The reason for the decrease in germination was the infection with bacterioses (pathogens are bacteria from the genera Pseudomonas Migula, Ervinia Winslow et al. emend. Hauben et al., Xanthomonas Dowson). fusarium (pathogens are fungi of the genus Fusarium Link.) also affected seeds, but to a lesser degree and it is often manifested itself together with bacteriosis. We observed alternaria blight (pathogens are Alternaria Ness) affection in all years of research, but not in every sample. Cercospora blight (pathogen is Cercospora Fresen.) appeared only on the seeds of the 2018 harvest. Moreover, in all the years of research, the infective matter of mold fungi of the genera Penicillium Link. (up to $4.5 \%$ ), Aspergillus Ness. (up to $2.1 \%$ ),

*Corresponding author: charel@yandex.ru 
and Mucor Fresen. (up to $22.1 \%$ ) was present on the seed coat of soybean seeds, but they had no effect on germination ability [3].

The presowing treatment with chemical disinfectants is the main method of seed disinfection. However, despite the importance of chemicals in disease control, there is a problem of resistance of phytopathogens to fungicides. As a result, higher dosages are used and new chemical compounds are introduced that cause contamination of food and the environment with toxic substances, as well as increase the cost of food production [4]. In this regard, currently, there is an increased interest in environmentally sound and relatively safe biopreparations, which are becoming a valid alternative to chemical pesticides.

The strategy of modern biological plant protection includes the use of biotic substances (antibiotics and substances of plant origin) and the application of biopreparations based on live cultures of microorganisms.

One of the trends in biocontrol is the development and application of biopreparations based on antagonist bacteria that can synthesize a wide range of antibiotics and other metabolites active against bacteria and fungi that cause plant diseases in agriculture [5-8]. Bacteria of the genus Bacillus and Pseudomonas produce various compounds that not only participate in the pathogens biocontrol, but also stimulate plant growth (PGPP), which makes them potential candidates for most agricultural and biotechnological applications [9-11]. Trichoderma spp. has the greatest potential among fungi-antagonists, the strains of which are widely used all over the world as biocontrol agents and plant biostimulants on many agricultural crops. Some Trichoderma strains are capable of stimulating plant growth and defense responses [12-14], including those in soybean [15]. Fungi of the genus Chaetomium are also known for their antagonistic activity against soil and seed pathogens [16-18].

Thus, the aim of our research was to evaluate the effectiveness of soybean seeds treatment with biopreparations based on bacterial and fungal strains in the laboratory conditions against the main pathogens that reduce germination.

\section{Materials and methods}

The objects of research were the soybean variety Slavia (breeding of V.S. Pustovoit AllRussian Research of Oil Crops), commercial biopreparations Fitosporin-M, WP ( $>2$ billion CFU/g) based on the strain 26 D Bacillus subtilis, Trichoderma Veride 471 ( $>$ billion spores/g) and Fitolavin, SC (BA-120000 removal unit/ml, 32 g/l) - phytobacteriomycin, an antibiotic of the streptotri group, as well as the laboratory samples of biopreparations based on the strains 14-3 Pseudomonas chlororaphis, LC (3.5x1010 CFU/g), Xk-1 Chaetomium olivacium, LC $\left(1.3 \times 10^{8} \mathrm{CFU} / \mathrm{g}\right)$ and Xk-1 Ch. olivacium, WP $\left(1.0 \times 10^{9} \mathrm{CFU} / \mathrm{g}\right)$, developed in the laboratory of biomethod of V.S. Pustovoit All-Russian Research Institute of Oil Crops [19, 20]. We chose the chemical pesticide TMTD, WSC (thiram $400 \mathrm{~g} / \mathrm{l}$ ), recommended for use the Russian Federation on soybean against seed mold, Ascochyta blight, Fusarium and bacteriosis, as a standard.

In order to determine the effect of biopreparations and the laboratory samples of biopreparations on the seeds and seedlings of soybean, we placed the treated seeds for germination in sterile rolls of filter paper moistened with sterile tap water in a moist chamber for 7 days at a temperature of $+25^{\circ} \mathrm{C}$. We determined the germination ability by the total number of normally germinated seeds according to GOST 12038-84. We classified the seeds with soft decomposed endosperm, blackened or rotten germs, seedlings with dead (partially or completely) roots, cotyledons, budlets, hypocotyl, epicotyl as unfruitful. We classified hard and imbibed non-germinated seeds with no signs of affection by any diseases as non-germinated. The length and weight of the root and seedling were the 
parameters for analyzing the effect on soybean seedlings. We calculated the plant density at the stage of full germination on an area of $1 \mathrm{~m}^{2}$ in course of 4 replications.

\section{Research results}

Bacteriosis and fusarium affection was the main reason for the decrease in seed germination. All tested biopreparations showed a protective effect. Due to the decrease in seed infection, the number of normally germinated seeds was higher in the variants than in the control - by 5.0-19.0\%. The maximum germination was in the variants with $14-3$ P. chlororaphis $(91.0 \%)$ and Fitosporin-M $(90.0 \%)$. Also, we observed a high percentage of germinated seeds in the variants with Xk-1 Ch. Olivacium $(86.0-87.0 \%)$ and standard TMTD (85.5\%) (Table 1).

Table 1. The effect of biopreparations on the laboratory germination and pathogenic microflora of soybean seeds (V.S. Pustovoit All-Russian Research Institute of Oil Crops, 2020)

\begin{tabular}{|c|c|c|c|c|c|c|c|}
\hline \multirow{3}{*}{ Variant } & \multirow{3}{*}{$\begin{array}{c}\text { Applica- } \\
\text { tion rate, } \\
1 / \mathrm{t}, \mathrm{kg} / \mathrm{t}\end{array}$} & \multirow{3}{*}{$\begin{array}{l}\text { Labora- } \\
\text { tory } \\
\text { germina- } \\
\text { tion, } \%\end{array}$} & \multicolumn{3}{|c|}{$\begin{array}{c}\text { Bilogical effectiveness, } \\
\%\end{array}$} & \multicolumn{2}{|c|}{$\begin{array}{l}\text { Plant } \\
\text { density, }\end{array}$} \\
\hline & & & \multirow{2}{*}{ 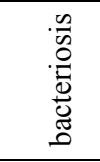 } & \multirow{2}{*}{ 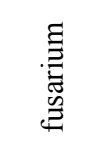 } & \multirow{2}{*}{ 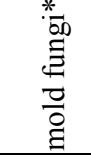 } & & \\
\hline & & & & & & $\mathrm{pcs} / \mathrm{m}^{2}$ & $\begin{array}{l}\% \text { to } \\
\text { con- } \\
\text { trol }\end{array}$ \\
\hline Control (without treatment) & - & 72.0 & $25.0 * *$ & $7.5^{* *}$ & $8.5^{* *}$ & 30.2 & - \\
\hline TMTD, WSC (standard) & 6.0 & 85.5 & 54.0 & 73.3 & 100 & 34.6 & 14.6 \\
\hline Fitosporin-M, WP & 2.0 & 90.0 & 64.0 & 20.0 & 11.8 & 33.8 & 11.9 \\
\hline Fitolavin, SC & 2.0 & 76.0 & 12.0 & 6.7 & 0 & 34.8 & 15.2 \\
\hline Trichoderma Veride 471, WP & 2.5 & 81.0 & 48.0 & 80.0 & 94.1 & 33.4 & 10.0 \\
\hline 14-3 P. chlororaphis, LC & 3.0 & 91.0 & 64.0 & 86.7 & 76.5 & 35.0 & 15.9 \\
\hline Xk-1 Ch. olivacium, LC & 3.0 & 86.0 & 44.0 & 33.3 & 29.4 & 31.5 & 4.3 \\
\hline Xk-1 Ch. olivacium, WP & 0.05 & 87.0 & 48.0 & 73.3 & 76.5 & 32.6 & 7.9 \\
\hline \multicolumn{6}{|l|}{$\mathrm{HCP}_{05}$} & 3.75 & - \\
\hline
\end{tabular}

* fungi of the generaPenicillium Link. and Aspergillus Ness.;

** the number of affected seeds in the control.

14-3 P. chlororaphis and Fitosporin-M (64.0\%) showed the maximum biological effectiveness against bacteriosis against the background of the control affection of $25.0 \%$, which exceeded the efficiency of the standard by $10.0 \%$. We also observed a protective effect in the variants with Trichoderma Veride 471 (48.0 \%) and Xk-1 Ch. olivacium (44.0-48,0 \%). 14-3 P. chlororaphis (86.7\%), Trichoderma Veride 471 (80.0\%) and Xk-1 Ch. olivacium, СП $(73.3 \%)$ showed the best results against fusarium, with the efficiency of the chemical standard TMTD of $73.3 \%$. The chemical standard TMTD showed $100 \%$ effectiveness against the mold fungi of the genera Penicillium and Aspergillus. Among the biopreparations, Trichoderma Veride 471 (94.1 \%), 14-3 P.chlororaphis and Xk-1 Ch. olivacium, СП (76.5\%) efficiently decreased their number.

The field tests of biopreparations have confirmed the data obtained in the laboratory. In all variants of the experiment, the plant density at the stage of full germination was 4.3-15.9\% higher than in the control. Seed treatment with Fitolavin, SC and 14-3, LC provided and increase in plant density by 15.2 and $15.9 \%$, respectively, compared with the control and exceeded the result of the chemical standard TMTD (Table 1).

In the laboratory experiment, in addition to the protective effect, we observed a positive effect of biopreparations on seedlings in the terms of stimulation of their growth. 14-3 was 
the most effective in all parameters, providing, in comparison with the control, an increase in the root length (RL) by $13.7 \%$, the seedling (SL) by $8.4 \%$, the root weight (RW) by $25.0 \%$, the seedling weight (SW) by $11.9 \%$. Xk-1, WP also showed a good stimulating effect on the root system (RL - by $13.5 \%$, RW - by $18.8 \%$ ), however, the effect on the seedling was insignificant (SL - by $9.8 \%$, SW - by $1.2 \%$ ). Trichoderma Veride 471 had the maximum stimulating effect on the root length - by $29.0 \%$, while the root weight was at the level with the control. Fitosporin-M contributed to a significant increase in the seedling length and weight (by 24.4 and $6.0 \%$, respectively), while the root system of seedlings was less developed than in the control variant (Table 2).

Table 2. The effect of seed treatment with biopreparations and the laboratory samples of biopreparations based on the promising strains of antagonists on the soybean seedlings (V.S. Pustovoit All-Russian Research Institute of Oil Crops, 2020)

\begin{tabular}{|l|c|c|c|c|c|c|c|c|}
\hline \multirow{2}{*}{\multicolumn{1}{|c|}{ Variant }} & \multicolumn{2}{|c|}{ Root length } & \multicolumn{2}{c|}{ Root weight } & \multicolumn{2}{|c|}{ Seedling length } & Seedling weight \\
\cline { 2 - 10 } & $\mathrm{cm}$ & $\begin{array}{c}\% \text { to } \\
\text { control }\end{array}$ & $\mathrm{g}$ & $\begin{array}{c}\% \text { to } \\
\text { control }\end{array}$ & $\mathrm{cm}$ & $\begin{array}{c}\% \text { to } \\
\text { control }\end{array}$ & $\mathrm{g}$ & $\begin{array}{c}\% \text { to } \\
\text { control }\end{array}$ \\
\hline Control (without treatment) & 11.20 & - & 0.16 & - & 5.50 & - & 0.84 & - \\
\hline TMTD, WSC (standard) & 11.83 & 5.6 & 0.15 & 0 & 6.31 & 14.7 & 0.85 & 1.2 \\
\hline Fitosporin-M, WP & 11.16 & 0 & 0.15 & 0 & 6.84 & 24.4 & 0.89 & 6.0 \\
\hline Fitolavin, SC & 11.13 & 0 & 0.17 & 6.3 & 5.53 & 1.9 & 0.84 & 0 \\
\hline Trichoderma Veride 471, WP & 14.45 & 29.0 & 0.16 & 0 & 5.90 & 7.3 & 0.83 & 0 \\
\hline 14-3 P.chlororaphis, LC & 12.73 & 13.7 & 0.20 & 25.0 & 5.96 & 8.4 & 0.94 & 11.9 \\
\hline Xk-1 Ch. olivacium, LC & 12.19 & 8.8 & 0.17 & 6.3 & 5.67 & 3.1 & 0.81 & 0 \\
\hline Xk-1 Ch. olivacium, WP & 12.71 & 13.5 & 0.19 & 18.8 & 6.04 & 9.8 & 0.85 & 1.2 \\
\hline HCP05 & 1.28 & - & 0.02 & - & 0.91 & - & 0.04 & - \\
\hline
\end{tabular}

\section{Conclusions}

The laboratory sample of the biopreparation based on the strain 14-3 P. chlororaphis, LC had the best protective effect against the complex of pathogens of soybean seed infection and the maximum growth-stimulating effect on soybean seedlings. We also observed high efficiency in the variants with the treatment of seeds with the biopreparations Trichoderma Veride 471, WP, Fitosporin-M, WP and the laboratory sample of biopreparation based on the strain Xk-1 Ch. olivacium, WP.

\section{References}

1. V.A. Chulkina, E.Y. Toropova, G.Y. Stetsov, Integrated plant protection: phytosanitary systems and technologies, 670 (2009)

2. V.M. Lukomets, N.I. Bochkarev, N.M. Tishkov and all, Plant protect. and quarantine, 1, 37 (2019)

3. D.A. Kurilova, Collection of scientific articles of «Omsk ANC», 200 (2020)

4. F.P.Carvalho, Env. Science \& Policy, 9, 685 (2006)

5. Y. Lirong, X. Quana, B. Xuea, P.H. Goodwinb, S. Lua, J. Wanga, W. Dua, C. Wua, Biol. Control, 85, 52 (2015)

6. P. Vejan, R. Abdullah, T. Khadiran, S. Ismail, B.A. Nasrulhaq, Molec., 21, 1 (2016)

7. R. Backer, J.S. Rokem, G. Ilangumaran, J. Lamont, D. Praslickova, E. Ricci, S. Subramanian, D.L. Smith, Front. Plant. Sci., 9, 1473 (2018) 
8. H.H. Nawaz, M.N. Rajaofera, Q. He, U. Anam, C. Lin, W. Miao, Pesticide Biochem. Physiol., 146, 33 (2018)

9. D. Miljaković, J.Marinković, S.T. Balešević. Microorganisms, 8, 1037 (2020)

10. J. Pathma, G.R. Rahul, K.R. Kamaraj, R. Subashri, N. Sakthivel, J. of Bio. Control, 25, $165(2011)$

11. B.C. Agaras, M. Scandiani, A. Luque, L. Fernández, F. Farina, M. Carmona, M. Gally, A. Romero, L. Wall, C. Valverde, Biological Control, 90, 173 (2015)

12. I.S. Druzhinina, V. Seidl-Seiboth, A. Herrera-Estrella, B.A. Horwitz, Ch.M. Kenerley, E. Monte, P. Mukherjee, S. Zeilinger, I.V. Grigoriev \& Ch.P. Kubicek, Nature Reviews Microbiol., 9, 749 (2011)

13. M.H. El Komy, A.A. Saleh, A. Eranthodi, Y.Y. Molan, Plant Pathol. J., 31, 50 (2015)

14. L. Naher, U.K. Yusuf, A. Ismail, K. Hossain. Pak, J. Bot, 46, 1489 (2014)

15. R.P.Johna, R.D. Tyagia, D. Prévost, S.K. Brara, S. Pouleur, R.Y. Surampallic, Crop Protection, 29, 1452 (2011)

16. G. Zhang, F. Wang, J. Qin, D. Wang, J. Zhang, Y. Zhang, S. Zhang, H. Pan, Biol. Control, 64, 90 (2013)

17. J.-H. Park, G.J. Choi, K.S. Jang, H.K. Lim, H.T. Kim, K.Y. Cho, J.-C. Kim. FEMS Microbiol. Letters, 252, 309 (2005)

18. S.S. Zhao, Y.Y. Zhang, W. Yan, L.L. Cao, Y. Xiao, Y.H. Microbiol. Lett., 3, 287 (2017)

19. L.V. Maslienko, D.A. Kurilova,Oil crop. Scientific-technical Byul. VNIIMK, 2 (166), 73 (2016)

20. D.A. Kurilova, L.V. Maslienko, Oil crop. Scientific-technical Byul. VNIIMK, 3 (167), 70 (2016) 